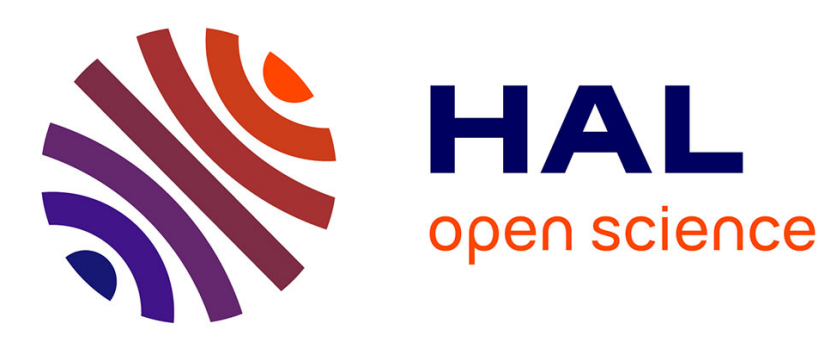

\title{
Stability during cooking of anthelmintic veterinary drug residues in beef
}

Kevin Mark Cooper, Michelle Whelan, Martin Danaher, David Glenn

Kennedy

\section{- To cite this version:}

Kevin Mark Cooper, Michelle Whelan, Martin Danaher, David Glenn Kennedy. Stability during cooking of anthelmintic veterinary drug residues in beef. Food Additives and Contaminants, 2011, 28 (2), pp.155. 10.1080/19440049.2010.542775 . hal-00660037

\section{HAL Id: hal-00660037 https://hal.science/hal-00660037}

Submitted on 15 Jan 2012

HAL is a multi-disciplinary open access archive for the deposit and dissemination of scientific research documents, whether they are published or not. The documents may come from teaching and research institutions in France or abroad, or from public or private research centers.
L'archive ouverte pluridisciplinaire HAL, est destinée au dépôt et à la diffusion de documents scientifiques de niveau recherche, publiés ou non, émanant des établissements d'enseignement et de recherche français ou étrangers, des laboratoires publics ou privés. 


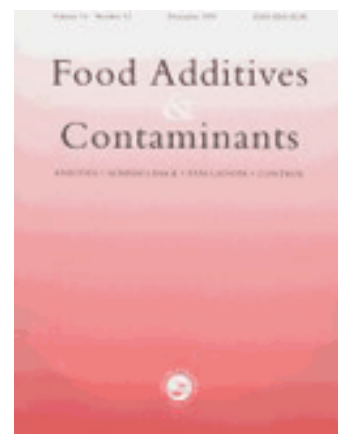

\section{Stability during cooking of anthelmintic veterinary drug residues in beef}

\begin{tabular}{|r|l|}
\hline Journal: & Food Additives and Contaminants \\
\hline Manuscript ID: & TFAC-2010-342.R1 \\
\hline Manuscript Type: & Original Research Paper \\
\hline Author: & 16-Nov-2010 \\
\hline Complete List of Authors: & $\begin{array}{l}\text { Cooper, Kevin; Queen's University Belfast, School of Biological } \\
\text { Sciences } \\
\text { Whelan, Michelle; Teagasc, Food Safety } \\
\text { Danaher, Martin; Teagasc, Food Safety } \\
\text { Kennedy, David; Chemical Surveillance Branch, VSD, AFBI }\end{array}$ \\
\hline Methods/Techniques: & LC/MS \\
\hline Additives/Contaminants: & Veterinary drug residues \\
\hline Food Types: & Meat \\
\hline & $\quad$ SCHOLARONE ${ }^{\text {M }}$ \\
\hline &
\end{tabular}




\title{
Stability during cooking of anthelmintic veterinary drug residues in beef
}

K.M. Cooper ${ }^{\mathrm{a}}$, M. Whelan ${ }^{\mathrm{b}}$, M. Danaher ${ }^{\mathrm{b}}$ and D.G. Kennedy ${ }^{\mathrm{c} *}$

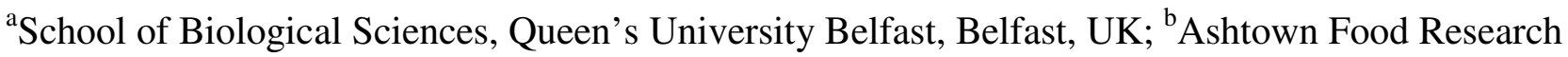 \\ Centre, Teagasc, Dublin, Ireland and ${ }^{c}$ Veterinary Sciences Division, Agri-Food and Biosciences \\ Institute, Stoney Road, Stormont, Belfast BT4 3SD, UK
}

CORRESPONDING AUTHOR:

Dr D. Glenn Kennedy E-mail: glenn.kennedy@afbini.gov.uk 


\begin{abstract}
Anthelmintic drugs are widely used for treatment of parasitic worms in livestock but little is known about the stability of their residues in food under conventional cooking conditions. As part of the European Commission-funded research project ProSafeBeef, cattle were medicated with commercially available anthelmintic preparations, comprising 11 active ingredients (corresponding to 21 marker residues). Incurred meat and liver were cooked by roasting $\left(40 \mathrm{~min}\right.$ at $\left.190^{\circ} \mathrm{C}\right)$ or shallow frying (muscle 8-12 min, liver 14-19 min) in a domestic kitchen. Raw and cooked tissues and expressed juices were analysed using a novel multi-residue dispersive solid phase extraction method (QuECheRS) coupled with Ultra Performance Liquid Chromatography-Tandem Mass Spectrometry. After correction for sample weight changes during cooking, no major losses were observed for residues of oxyclozanide, clorsulon, closantel, ivermectin, albendazole, mebendazole or fenbendazole. However, significant losses were observed for nitroxynil (78\% in fried muscle, $96 \%$ in roast muscle), levamisole (11\% in fried muscle, $42 \%$ in fried liver), rafoxanide (17\% in fried muscle, $18 \%$ in roast muscle) and triclabendazole (23\% in fried liver, $47 \%$ in roast muscle). Migration of residues from muscle into expressed cooking juices varied between drugs, constituting $0 \%$ to $17 \%$ (levamisole) of total residues remaining after cooking. With the exception of nitroxynil, residues of anthelmintic drugs were generally resistant to degradation during roasting and shallow frying. Conventional cooking cannot, therefore, be considered a safeguard against ingestion of residues of anthelmintic veterinary drugs in beef.
\end{abstract}

Keywords: anthelmintics; veterinary drug residues; QuEChERS; stability; cooking; beef; ProSafeBeef. 


\section{Introduction}

A wide range of veterinary drugs are used in prophylaxis and treatment of endoparasitic infections and ectoparasitic infestations in domestic livestock. Anthelmintic drugs used to control nematode (roundworm), cestode (tapeworm) and trematode (fluke) infections include various benzimidazole compounds (including fenbendazole, triclabendazole, mebendazole and albendazole), imidazothiazoles (particularly levamisole), macrocyclic lactones (including ivermectin) and a range of flukicidal compounds (including oxyclozanide, rafoxanide, closantel, nitroxynil and clorsulon). Concerns over the toxicity of some of these drugs (McKellar and Scott 1990; Lankas and Peter 1992) led the European Union to establish Maximum Residue Limits (MRLs) for their residues in tissues of food-producing species (collated in European Commission 2010). Drugs, other than those listed in this legislation, are not licensed for use in food-producing animals and therefore their residues ought not to be present in food. The occurrence and determination of benzimidazole and macrocyclic lactone residues in biological matrices have recently been reviewed by Danaher et al. (2006; 2007). Food safety and the exposure of the consumer to chemical residues in food are of continuing concern and there is an ongoing need for new analytical techniques and information on the occurrence of potentially harmful residues of veterinary drugs in our food. ProSafeBeef (www.prosafebeef.eu) is a EU Sixth Framework Integrated Project involving 41 leading research and industrial organisations working in 18 different countries, aiming to advance beef safety and the diversification of the European beef sector. Under this project, a novel analytical method, based on state-of-the-art ultra-performance liquid chromatography-tandem mass spectrometry (UPLCMS/MS), was developed simultaneously to detect 38 anthelmintic drug residues in bovine tissues (Kinsella et al. 2010; Whelan et al. 2010). This technique was subsequently applied in a survey of retail beef across Europe to determine the prevalence of anthelmintic drug residues in meat available to the European consumer, and in a study of the stability of anthelmintic drugs in solution, tissue extracts and stored tissue to assist the analyst in accurate quantification of residues of these drugs in food. Results of both these studies will be published elsewhere. Studies of the attitudes of 
consumers towards the safety of the meat they consume were also a major pillar of ProSafeBeef research (Van Wezemael et al. 2010). Should unacceptable residues of anthelmintic drugs find their way into our foods, legislators, analysts and consumers alike will wish to know if such residues are destroyed when that food is cooked.

Between 1995 and 2005, Rose and co-workers in the UK Central Science Laboratory demonstrated that residues of a range of veterinary drugs exhibit varying degrees of stability during cooking and, therefore, that cooking influences the level of risk posed by such residues (Rose et al. 1996). This compound-dependent stability during cooking is supported by studies of nitrofuran residues by Cooper and Kennedy (2007) and malachite green residues by Mitrowska et al. (2007). However, to date, the assessment of the stability of anthelmintic drug residues in foods has been piecemeal and limited to the effects of pasteurisation on the macrocyclic lactones, including ivermectin, in milk (Imperiale et al. 2009; Cerkvenik et al. 2001), and the effects of various cooking procedures on ivermectin in porcine liver and bovine, porcine and salmon muscle (Rose et al. 1998; Slanina et al. 1989), levamisole in bovine and porcine muscle (Rose et al. 1995a; Hsu and Epstein 1993) and oxfendazole in bovine liver (Rose et al. 1997).

To complement the outcomes of the ProSafeBeef European retail beef survey and aid relevant authorities and the consumer in assessing their exposure to anthelmintic drug residues, the current study set out to determine the stability during cooking, by frying and roasting, of a wide range of anthelmintic residues in meat and liver of cattle treated with commercially available veterinary parasiticide preparations. 


\section{Materials and methods}

\section{Materials and instrumentation}

Reference standards and internal standards analysed in this study are listed in Table 1 along with their sources and abbreviated names. Standards were obtained from Sigma-Aldrich (Poole, UK), Witega Laboratorien Berlin-Adlershof (Berlin, Germany), Janssen Animal Health (Beerse, Belgium), Pfizer Animal Health (Sandwich, UK) and QuChem (formerly of Belfast, UK). Unless stated, all other chemicals were obtained from Sigma-Aldrich.

Commercially available parasiticide preparations were purchased from the following manufacturers: Levafas Diamond (Norbrook Laboratories Ltd.; Newry, UK), Curafluke 10\% (Univet Ltd.; Cootehill, Ireland), Supaverm ${ }^{\mathrm{TM}}$ Oral Suspension (Janssen Animal Health; High Wycombe, UK), Valbazen® 10\% (Pfizer Animal Health; Ringaskiddy, Ireland), Fasinex Super® 19.5\% (Novartis Animal Health Ireland Ltd.; Waterford, Ireland), Deldrax ${ }^{\circledR} 34 \%$ (Intervet Ireland Ltd.; Dublin, Ireland) and Ivomec Super® Injection for Cattle (Merial Animal Health; Harlow, UK).

An Acquity UPLC® binary pump and sample management system (Waters Corporation, Manchester, UK) coupled to a Quattro Premier ${ }^{\mathrm{TM}}$ XE tandem mass spectrometer (Waters Corporation), both operating under MassLynx ${ }^{\mathrm{TM}}$ software, were used for sample analysis. The mass spectrometer operated under Electrospray Ionisation (ESI) with rapid polarity switching. Data acquisition was in Multiple Reaction Monitoring mode (MRM) with a total run time of 11 min. Data analysis was performed using Waters TargetLynx ${ }^{\mathrm{TM}}$ software. MS source settings were as follows: capillary voltage $3.0 \mathrm{kV}(\mathrm{ESI}+)$ and $2.2 \mathrm{kV}$ (ESI-), source temperature $150^{\circ} \mathrm{C}$, desolvation temperature $400^{\circ} \mathrm{C}$, cone nitrogen gas flow $150 \mathrm{~L} \mathrm{~h}^{-1}$, desolvation nitrogen gas flow $800 \mathrm{~L} \mathrm{~h}^{-1}$. The UPLC system was equipped with an Acquity HSS T3 UPLC analytical column $(100 \times 2.1 \mathrm{~mm})$ packed with HSS $\mathrm{C}_{18}(1.8 \mu \mathrm{m})$ and an in-line filter unit $(0.2 \mu \mathrm{m}, 2.1 \mathrm{~mm})$ (Waters Corporation), 
heated to $60^{\circ} \mathrm{C}$. A binary gradient mobile phase was applied at a flow rate of $0.6 \mathrm{~mL} \mathrm{~min}^{-1}$, phase A being $0.01 \%$ acetic acid in acetonitrile:water $(10: 90, \mathrm{v} / \mathrm{v})$, phase $\mathrm{B}$ being $5 \mathrm{mM}$ ammonium formate in methanol:acetonitrile (75:25, v/v). The gradient profile was: (1) 0-0.5 min, 100\% A, (2) 5 min, 50\% A, (3) $7 \mathrm{~min}, 10 \% \mathrm{~A}$, (4) $8.5 \mathrm{~min}, 10 \% \mathrm{~A}$, (5) $8.51 \mathrm{~min}, 0 \% \mathrm{~A}$, (6) $9.0 \mathrm{~min}, 0 \% \mathrm{~A}$, (7) 9.01 $\min , 100 \% \mathrm{~A}$, (8) $11 \mathrm{~min} 100 \%$ A. The UPLC weak wash was methanol:water (20:80, v/v) and strong wash was methanol:propan-2-ol:water (80:10:10, v/v).

A Testo 915-1 Universal probe thermometer was obtained from Testo AG (Lenzkirch, Germany). Tissues were minced in a domestic food processor before homogenisation in a SL2 laboratory homogeniser (Silverson Machines Ltd., Chesham, UK). QuEChERS dispersive clean-up tubes (1.5 $\mathrm{g} \mathrm{MgSO}_{4}$ and $0.5 \mathrm{~g} \mathrm{C}_{18}$ in $50 \mathrm{~mL}$ centrifuge tubes) were obtained from UCT (Bristol, PA, USA). QuEChERS extraction salts, anhydrous $\mathrm{MgSO}_{4}(4 \mathrm{~g})$ and $\mathrm{NaCl}(1 \mathrm{~g})$, were obtained from SigmaAldrich and pre-weighed in-house.

[INSERT TABLE 1 ABOUT HERE]

\section{Production of incurred bovine tissues}

Seven pasture-fed beef cattle (male, 16-17 months of age, approximately $450 \mathrm{~kg}$ body weight) were treated with commercially available parasiticide preparations (comprising 11 active ingredients corresponding to 21 marker residues) at the manufacturers' recommended doses and routes (subcutaneous injection or oral drench) split half-and-half over two consecutive days (Table 2). Administration was staggered over two days to encourage the formation of both parent and metabolite drug residues in the tissues. Short withdrawal periods of one or two days were observed after the second dose before cattle were slaughtered and Longissimus dorsi muscle (sirloin/filet steak) and liver were sampled. Tissues were stored at $-20^{\circ} \mathrm{C}$ prior to analysis. 


\section{[INSERT TABLE 2 ABOUT HERE]}

\section{Cooking of incurred beef and liver}

One portion of $L$. dorsi muscle and one portion of liver were selected from each medicated cow. After thawing to room temperature, adjoining pieces of muscle were sliced for frying (mean $185 \mathrm{~g}$ ) and roasting (mean $300 \mathrm{~g}$ ). A third adjoining slice was retained for analysis without cooking. Single slices of liver (mean $170 \mathrm{~g}$ ) were taken for frying and adjoining uncooked slices retained for analysis without cooking. Excess juices and blood were removed from each sample using absorbent tissue before weighing immediately prior to cooking (or before mincing of uncooked samples). Cooked samples were re-weighed after cooling to room temperature and removal of excess juices. Cooked and raw samples were then individually minced in a domestic food processor and re-frozen at $-20^{\circ} \mathrm{C}$ prior to analysis by LC-MS/MS. Cooking conditions were as follows.

Roasting. Muscle was roasted for $40 \mathrm{~min}$ at $190^{\circ} \mathrm{C}$ on the middle shelf of a pre-heated fan-assisted domestic oven, while wrapped in aluminium foil in an uncovered tray. All juices expressed during roasting were collected and weighed.

Frying. Muscle was fried for 4-6 min each side (depending on sample size, to give medium cooked meat) on a high heat setting on a domestic ceramic hob, in a minimal volume of sunflower oil (one teaspoon) to prevent burning. Small volumes of expressed juices were collected following frying of the majority of muscle samples. Liver was fried in approximately $10 \mathrm{~mL}$ sunflower oil, searing for 2 min each side on a high heat setting, then frying on medium heat for a further 10-15 min, depending on sample size, to give well done cooked liver in the centre of the portion. Significant amounts of juices were not expressed during frying of liver.

The maximum internal temperature of each sample was measured on completion of cooking by inserting a digital penetration probe thermometer into the centre of the sample. 


\section{LC-MS/MS analysis}

Each sample, raw and cooked, was analysed in triplicate as described below. Juices were analysed in duplicate. Different sample types were stored under identical conditions at all times and analysed in the same analytical batch to avoid time-dependent (stability) differences in residue concentrations. This analytical method is based on the QuEChERS-UPLC-MS/MS protocol developed by Kinsella et al. $(2009 ; 2010)$ under the ProSafeBeef project.

Briefly, samples (10 g) were extracted by homogenisation in acetonitrile $(12 \mathrm{~mL})$. Phase separation was achieved by shaking homogenised samples with anhydrous $\mathrm{MgSO}_{4}(4 \mathrm{~g})$ and $\mathrm{NaCl}(1 \mathrm{~g})$. Following centrifugation, the supernatant was cleaned-up using dispersive SPE by vortex mixing with anhydrous $\mathrm{MgSO}_{4}(1.5 \mathrm{~g})$ and $\mathrm{C}_{18}$ sorbent $(0.5 \mathrm{~g})$. Following centrifugation, a portion of the extract (1-3 mL) was mixed with dimethylsulphoxide (DMSO, 0.5-1 mL) and the acetonitrile evaporated under nitrogen at $50^{\circ} \mathrm{C}$. The volumes of extract and DMSO employed were varied for a given analytical batch to keep the MS/MS signal within a linear range. Furthermore, highly concentrated samples were diluted with $L$. dorsi muscle or liver from untreated cattle, up to a total of $10 \mathrm{~g}$, prior to homogenisation. Extracted matrix calibration standard curves were prepared by fortifying $10 \mathrm{~g}$ of $L$. dorsi muscle or liver from untreated cattle with standard mixtures prior to homogenisation and extraction. Final extracts in DMSO were injected ( $4 \mu \mathrm{L})$ onto the AcquityPremier XE UPLC-MS/MS system described above. Ionisation polarities and internal standards applied are listed in Table 1. Calibration standards ( $n=5$ to 7 depending on range of linearity) were injected in duplicate with acceptable regression coefficients $\left(\mathrm{r}^{2}\right)$ above 0.98 for analytes employing isotopic internal standards and 0.95 for those employing non-isotopic internal standards (Table 1). Analyte concentrations in samples were calculated by comparing the ratio of the response of the analyte's base peak to the internal standard response with the same ratio in calibration curve standards, followed by a correction for any sample dilution applied prior to extraction. 


\section{Results and discussion}

Changes in anthelmintic drug residue concentrations during cooking are shown in Tables 3-5. Two cattle received medication containing levamisole - only data from that which received Levafas Diamond are presented. The concentrations detected in raw (uncooked) tissues were adjusted for sample weight changes resulting from the cooking procedures to give concentrations "expected after cooking". These expected concentrations were then compared with the concentrations detected after cooking and a two-tailed, unpaired Student's t-test applied to the triplicate analyses. Concentrations of the benzimidazoles are expressed as the sums of their parent compounds and/or metabolites as defined by Commission Regulation 37/2010 (European Commission 2010) which recently replaced Commission Regulation 2377/90 as an alphabetical listing of Maximum Residue Limits and marker residues for allowed pharmacologically active substances in foodstuffs of animal origin. Calculations of the concentrations of designated benzimidazole marker residues were as follows:

$$
\begin{aligned}
& \text { Albendazole: } \quad \mathrm{ABZ}=(0.943 \times \mathrm{ABZ}-\mathrm{SO})+\left(0.892 \times \mathrm{ABZ}-\mathrm{SO}_{2}\right)+\left(1.109 \times \mathrm{ABZ}-\mathrm{NH}_{2}-\mathrm{SO}_{2}\right) \\
& \text { Fenbendazole: } \quad \mathrm{FBZ}_{-\mathrm{SO}_{2}}=\mathrm{FBZ}_{-\mathrm{SO}_{2}}+(1.107 \times \mathrm{FBZ})+(1.051 \times \mathrm{FBZ}-\mathrm{SO}) \\
& \text { Mebendazole: } \quad \mathrm{MBZ}=\mathrm{MBZ}+\left(1.244 \times \mathrm{NH}_{2}-\mathrm{MBZ}\right)+(1.014 \times \mathrm{OH}-\mathrm{MBZ}) \\
& \text { Triclabendazole: } \text { KetoTCB }=\text { KetoTCB }+(0.916 \times \mathrm{TCB})+(0.878 \times \mathrm{TCB}-\mathrm{SO})+\left(0.842 \times \mathrm{TCB}-\mathrm{SO}_{2}\right)
\end{aligned}
$$

For those samples from which juices were expressed, mean residues detected in cooked tissue and juices were combined in absolute terms $(\mu \mathrm{g}$ residue in total cooked sample $+\mu \mathrm{g}$ residue in total cooked juices) to permit comparison with $\mu \mathrm{g}$ of residue in total uncooked sample (Tables 4-5). Replicate data $(n=3)$ from tissues and juices cannot be paired to give replicate concentration data for combined cooked samples, therefore a t-test cannot be applied. A t-test could be applied only to triplicate analyses of the tissue concentrations without reference to juice concentrations.

[INSERT TABLES 3, 4 AND 5 ABOUT HERE] 
Maximum internal sample temperatures during cooking ranged from 55 to $96^{\circ} \mathrm{C}$ (Tables 3-5). In keeping with the differing sample sizes and cooking times, higher internal temperatures were achieved during roasting of muscle $\left(\right.$ mean $88^{\circ} \mathrm{C}$ ) than frying $\left(\right.$ mean $\left.65^{\circ} \mathrm{C}\right)$. Liver, fried thoroughly for up to $19 \mathrm{~min}$, reached the highest temperatures (mean $91{ }^{\circ} \mathrm{C}$ ).

Major residue instability was evident only for nitroxynil which dropped by $96 \%$ in roast muscle and by $78 \%$ in fried muscle (Tables 4 and 5). Nitroxynil was not detected in uncooked liver. This disparity between nitroxynil concentrations in uncooked bovine muscle $\left(531 \mu \mathrm{g} \mathrm{kg}^{-1}\right)$ and liver $(<10$ $\mu \mathrm{g} \mathrm{kg}^{-1}$ ) is in keeping with a previous report indicating that up to $98 \%$ of nitroxynil was metabolised in the liver of treated cattle (EMEA 1999). Our observed loss of nitroxynil in muscle is in agreement with the limited data of Ekström and Slanina (1982) who saw the complete destruction of nitroxynil in beef boiled for $2 \mathrm{~h}$ and a loss of up to $55 \%$ when fried.

Smaller, but significant, losses of levamisole ( $42 \%$ in fried liver, $11 \%$ in fried muscle), rafoxanide (17\% in fried muscle, $18 \%$ in roast muscle) and triclabendazole (23\% in fried liver, $47 \%$ in roast muscle) were also seen in the current study.

A small loss of levamisole from fried bovine muscle (11\%) was observed. Rose et al. (1995a) saw no loss of levamisole during frying of incurred porcine muscle or in boiling water at $100^{\circ} \mathrm{C}$. Roasting bovine muscle in the current study led to a $17 \%$ loss of levamisole in the meat but this was wholly accounted for by the residue detected in the expressed juices (Table 5). Rose et al. (1995a) also demonstrated a loss of levamisole during roasting of porcine muscle but expressed juices were not analysed in that instance. Hsu and Epstein (1993) suggested that levamisole was stable under ordinary cooking conditions, although a $26 \%$ decrease was evident during broiling of porcine muscle. The present study, however, clearly demonstrated a $42 \%$ loss of levamisole during frying of incurred bovine liver (not studied by Rose). Given that levamisole migrated into expressed juices during roasting of muscle to a greater degree than any other residue in this study (17\% of 
Rafoxanide (Tables 3-5) was seen to decrease by $17-18 \%$ in cooked muscle and by $12 \%$ in fried liver (although this was not statistically significant). Caldow et al. (2009) demonstrated that rafoxanide was generally stable during storage, although degradation in fortified tissue and low concentration solvent solution was evident after one week storage at room temperature in daylight. The significance of a minor reduction (less than one fifth) in residues of a drug to which relatively low EU Maximum Residue Limits have been assigned $\left(30 \mu \mathrm{g} \mathrm{kg}^{-1}\right.$ bovine muscle and $10 \mu \mathrm{g} \mathrm{kg}^{-1}$ bovine liver; Table 2) is debatable. Consumers want their meat to be residue-free on the supermarket shelf, and on their plate, and will view such partial degradation of residues during cooking as no safeguard to their health or the perceived quality of their food. Furthermore, it cannot be discounted that residues of any compound lost during cooking are in fact being converted to unidentified products with equal or greater toxicity.

Triclabendazole was the only benzimidazole compound which exhibited instability during cooking when expressed as the sum of its metabolites as defined by Commission Regulation 37/2010 (European Commission 2010). Total triclabendazole fell by $23 \%$ in fried liver and by $47 \%$ in roast muscle. This two-fold difference in stability (cooking temperatures were comparable) may be due in part to the different starting metabolite concentrations in the uncooked tissues. $\mathrm{TCB}-\mathrm{SO}_{2}$ is the predominant metabolite in muscle, followed by TCB, while the reverse is the case in liver (Tables 3 and 4). However, in both tissues TCB-SO $\mathrm{S}_{2}$ exhibited higher percentage losses than TCB during cooking, leading to a substantially greater reduction in total triclabendazole residues in muscle than in liver. Total triclabendazole did not fall significantly when muscle was fried - the treatment 
which used the shortest time and lowest temperatures. In this case the predominant $\mathrm{TCB}-\mathrm{SO}_{2}$ metabolite concentration fell slightly but was off-set by an increase in TCB concentration. Of the four triclabendazole metabolites analysed, TCB-SO exhibited the largest percentage reductions during cooking, but it comprised only a small proportion (approximately 2\%) of total triclabendazole residues.

Minor statistically significant reductions $(6 \%)$ in total albendazole and total mebendazole residues were evident in roast muscle, but these can be considered negligible in the context of food safety. Analysis of the metabolites of albendazole suggests a shift towards higher $\mathrm{ABZ}-\mathrm{NH}_{2}-\mathrm{SO}_{2}$ concentrations when liver and muscle are fried, but this was not evident when muscle was roasted (Tables 3-5). Analysis of the metabolites of mebendazole suggested no shift in their relative concentrations during cooking with the exception of $\mathrm{NH}_{2}-\mathrm{MBZ}$ which doubled its concentration in liver during frying, leading to a considerable $86 \%$ increase in total mebendazole residues. This change was not replicated in cooked muscle in which the starting concentration of mebendazole residues was 10 fold lower than in liver. The source of this elevated $\mathrm{NH}_{2}-\mathrm{MBZ}$ in fried liver was not transformation of $\mathrm{MBZ}$ or $\mathrm{OH}-\mathrm{MBZ}$, and must therefore be attributed to other unidentified hepatic metabolites of mebendazole.

Rose et al. (1997) postulated the formation of an amine of oxfendazole (FBZ-SO) when cooking incurred bovine liver and concluded that, while cooking did not destroy the residues, it may affect the equilibrium between FBZ-SO, FBZ-SO ${ }_{2}, \mathrm{FBZ}$ and other unidentified fenbendazole metabolites in incurred tissue. The current study supports this assertion. FBZ-SO is a very minor metabolite in muscle and no significant change in total fenbendazole residues or shift in the relative concentrations of its metabolites was evident following cooking. Similarly, no significant drop in total fenbendazole residues was seen following frying of incurred liver although the concentration of FBZ-SO $\mathrm{SO}_{2}$ did fall by $80 \%$. 
In addition to ivermectin, the flukicides oxyclozanide, closantel and clorsulon exhibited no instability under cooking in the present study. However, statistically significant increases (27-29\%) were apparent for oxyclozanide and clorsulon after frying of muscle (Table 4). As postulated above for $\mathrm{NH}_{2}-\mathrm{MBZ}$, these increases may arise from transformation of other unidentified metabolites during cooking, although it is difficult to explain why they were not replicated in roast muscle or fried liver.

Migration of drug residues into expressed juices during cooking is one aspect of studies such as this which is difficult to control and to assess accurately. The availability of expressed juices is sample and operator-dependent, being affected by many factors including the fat and water contents of the tissue, cooking temperature, the physical treatment of the tissue (slicing, squeezing) and resting time post-cooking. Furthermore, the fate of any residues which do migrate into cooking juice is dependent upon consumer choice - the choice to discard juices or use them in sauces or gravy or to baste the meat. Culinary practices do not always fit neatly with analytical laboratory practices. Nevertheless, the evidence of the current study suggests that migration of anthelmintic drug residues into juices during roasting or shallow frying of beef or bovine liver is not a major consideration. With the exception of levamisole (17\% from roast muscle), residues in expressed juices constituted only $8 \%$ or less of the total residues remaining after cooking (Tables 4 and 5). The extent of drug residue migration into cooking juices is known to be dependent upon the 
compound ( $<2 \%$ for nicarbazin; Tarbin et al. 2005) and method of cooking (20\% for sulphamethazine from microwaved pig meat, but 54\% when pressure cooked; Rose et al. 1995b).

In summary, with the exception of nitroxynil, residues of anthelmintic drugs in beef and bovine liver were generally resistant to degradation during roasting and frying. Apparent increases in residue concentrations during cooking may be due to conversion of unidentified metabolites into the specified marker residues. Consequently, conventional domestic cooking cannot be considered a safeguard against ingestion of residues of commonly used anthelmintic veterinary drugs in beef.

How such findings impact upon the consumer of beef and their perception of beef quality is another aspect of the research conducted under the ProSafeBeef project. Verbeke et al. (2007) described how consumers of food do not differentiate significantly between different types of risk within a particular food group. For example, in the mind of the consumer dioxins in poultry, hormones in beef and antibiotics in pork were conflated and considered to be equivalent. Furthermore, risks in one food group can be erroneously attributed to another - for example, the belief that bovine spongiform encephalopathy (BSE) was a cause for concern in poultry (Verbeke 2001). A recent ProSafeBeef project study of European consumer perceptions of beef safety demonstrated that, rather than fearing the separate risks of contamination of their food by either "bugs" (microbiological risks) or "drugs" (chemical risks), consumers applied an overarching criterion such that safe beef was perceived as beef that is not bad for consumers' health ("It shouldn't be making me ill"; Van Wezemael et al. 2010). Consumers may thus apply the well-understood public advice on bacterial risks (store the meat properly and cook it thoroughly) believing that their vigilance will also afford a degree of protection against the health risks of chemical contaminants. The present study and much of the scientific literature demonstrate that such action affords the consumer little or no such protection against veterinary drug residues. This study adds weight to the general principle that veterinary drug residues in food are resistant to degradation under conventional 
cooking and supports the approach of minimising and controlling the use of veterinary medicines at source to safeguard both the health of the consumer and the profitability of food producers. 


\section{Acknowledgements}

The authors acknowledge the financial support of the European Commission for the project FOODCT-2006-36241 'ProSafeBeef' which funded this work. Grateful thanks are expressed to the farm and post-mortem room staff of AFBI Veterinary Sciences Division, Belfast. We thank Janssen Animal Health and Pfizer Animal Health UK for donating standard materials and the EU Community Reference Laboratory (BVL, Berlin, Germany) for the formulae for benzimidazole metabolite calculations. 


\section{References}

Caldow M, Sharman M, Kelly M, Day J, Hird S, Tarbin JA. 2009. Multi-residue determination of phenolic and salicylanilide anthelmintics and related compounds in bovine kidney by liquid chromatography-tandem mass spectrometry. J Chromatogr A 1216: 8200-8205.

Cerkvenik V, Doganoc DZ, Skubic V, Beek WMJ, Keukens HJ. 2001. Thermal and long-term freezing stability of ivermectin residues in sheep milk. Eur Food Res Technol. 213: 72-76.

Cooper KM, Kennedy DG. 2007. Stability studies of the metabolites of nitrofuran antibiotics during storage and cooking. Food Addit Contam. 24: 935-942.

Danaher M, De Ruyck H, Crooks SRH, Dowling G, O'Keeffe M. 2007. Review of methodology for the determination of benzimidazole residues in biological matrices. J Chromatogr B 845: 1-37.

Danaher M, Howells LC, Crooks SRH, Cerkvenik-Flajs V, O'Keeffe M. 2006. Review of methodology for the determination of macrocyclic lactone residues in biological matrices. $\mathbf{J}$ Chromatogr B 844: 175-203.

Ekström L-G, Slanina P. 1982. Determination and health-risk evaluation of nitroxynil residues in the edible tissues of cattle. Acta Vet Scand. 23: 313-324.

EMEA. 1999. Committee for Veterinary Medicinal Products: Nitroxinil Summary Report [Internet]. 7 June 1999. European Agency for the Evaluation of Medicinal Products. Available from: http://www.ema.europa.eu/ema/.

European Commission. 2010. Commission Regulation (EC) 37/2010, of 22 December 2010 on pharmacologically active substances and their classification regarding maximum residue limits in foodstuffs of animal origin. Off J Eur Comm. L15: 1-72.

Hsu SY, Epstein RL. 1993. Influence of cooking processing conditions on levamisole residues in swine muscle tissues. In: Haagsma N, Ruiter A, Czedikeysenberg PB, editors, Proceedings of EuroResidue II Conference on Residues of Veterinary Drugs in Food; 3-5 May 1993; Veldhoven, The Netherlands; p. 387-390. 
Imperiale FA, Farias C, Pis A, Sallovitz JM, Lifschitz A, Lanusse C. 2009. Thermal stability of antiparasitic macrocyclic lactones milk residues during industrial processing. Food Addit Contam. 26: 57-62.

Kinsella B, Lehotay SJ, Mastovska K, Lightfield AR, Furey A, Danaher M. 2009. New method for the analysis of flukicide and other anthelmintic residues in bovine milk and liver using liquid chromatography-tandem mass spectrometry. Anal Chim Acta 637: 196-207.

Kinsella B, Whelan M, Cantwell H, McCormack M, Furey A, Lehotay SJ, Danaher M. 2010. A dual validation approach to detect anthelmintic residues in bovine liver over an extended concentration range. Talanta 83: 14-24.

Lankas GR and Peter CP 1992. Induction of reversible urothelial cell hyperplasia in rats by clorsulon, a flukicide with weak carbonic-anhydrase inhibitory activity. Food Chem Toxicol. 30: 297-306.

McKellar QA and Scott EW 1990. The benzimidazole anthelmintic agents - a review. J Vet Pharmacol Ther. 13: 223-247.

Mitrowska K, posyniak A, Zmudzki J 2007. The effects of cooking on residues of malachite green and leucomalachite green in cup muscles. Anal Chim Acta 586: 420-425.

Rose MD, Argent LC, Shearer G, Farrington WHH. 1995a. The effect of cooking on veterinary drug residues in food: 2. levamisole. Food Addit Contam. 12: 185-194.

Rose MD, Bygrave J, Farrington WHH, Shearer G. 1996. The effect of cooking on veterinary drug residues in food: 4. oxytetracycline. Food Addit Contam. 13: 275-286.

Rose MD, Farrington WHH, Shearer G. 1995b. The effect of cooking on veterinary drug residues in food: 3. sulphamethazine (sulphadimidine). Food Addit Contam. 12: 739-750.

Rose MD, Farrington WHH, Shearer G. 1998. The effect of cooking on veterinary drug residues in food: 7. ivermectin. Food Addit Contam. 15: 157-161.

Rose MD, Shearer G, Farrington WHH. 1997. The effect of cooking on veterinary drug residues in food: 5. oxfendazole. Food Addit Contam. 14: 15-26. 
Slanina P, Kuivinen J, Ohlsen C, Ekström L-G. 1989. Ivermectin residues in the edible tissues of swine and cattle: effect of cooking and toxicological evaluation. Food Addit Contam. 6: 475481.

Tarbin JA, Bygrave J, Bigwood T, Hardy D, Rose M, Sharman M. 2005. The effect of cooking on veterinary drug residues in food: Nicarbazin (dinitrocarbanilide component). Food Addit Contam. 22: 1126-1131.

Van Wezemael L, Verbeke W, Kugler JO, De Barcellos MD, Grunert KG. 2010. European consumers and beef safety: Perceptions, expectations and uncertainty reduction strategies. Food Control 21: 835-844.

Verbeke W. 2001. Beliefs, attitude and behaviour towards fresh meat revisited after the Belgian dioxin crisis. Food Qual Prefer. 12: 489-498.

Verbeke W, Frewer LJ, Scholdere J, De Brabander HF. 2007. Why consumers behave as they do with respect to food safety and risk information. Anal Chim Acta 586: 2-7.

Whelan M, Kinsella B, Furey A, Moloney M, Cantwell H, Lehotay SJ, Danaher M. 2010. Determination of anthelmintic drug residues in milk using ultra high performance liquid chromatography-tandem mass spectrometry with rapid polarity switching. J Chromatogr A 1217: 4612-4622. 
Table 1. Reference and internal standard abbreviations, sources, ESI modes and applied internal standards.

\begin{tabular}{|c|c|c|c|c|}
\hline Standard & Abbreviation & Source & ESI mode & Internal standard \\
\hline Clorsulon & CLORS & Sigma-Aldrich & - & DNC-D8 \\
\hline Closantel & CLOSAN & Sigma-Aldrich & - & ТВСР \\
\hline Nitroxynil & NITROX & Sigma-Aldrich & - & TBCP \\
\hline Oxyclozanide & OXYCLOZ & Sigma-Aldrich & - & TBCP \\
\hline Rafoxanide & RAFOX & Sigma-Aldrich & - & DNC-D8 \\
\hline Levamisole & LEVAM & Sigma-Aldrich & + & LEVAM-D5 \\
\hline Ivermectin B1a & IVER & Sigma-Aldrich & + & SELA \\
\hline Albendazole & $\mathrm{ABZ}$ & Sigma-Aldrich & + & ABZ-D3 \\
\hline Albendazole Sulphoxide & ABZ-SO & Witega & + & ABZ-SO-D3 \\
\hline Albendazole Sulphone & $\mathrm{ABZ}-\mathrm{SO}_{2}$ & Witega & + & $\mathrm{ABZ}-\mathrm{SO}_{2}-\mathrm{D} 3$ \\
\hline Albendazole 2-Amino-Sulphone & $\mathrm{ABZ}-\mathrm{NH}_{2}-\mathrm{SO}_{2}$ & Witega & + & ABZ-D3 \\
\hline Fenbendazole & FBZ & Sigma-Aldrich & + & FBZ-D5 \\
\hline Fenbendazole-Sulphoxide & FBZ-SO & Sigma-Aldrich & + & FBZ-SO-D5 \\
\hline Fenbendazole-Sulphone & $\mathrm{FBZ}_{-\mathrm{SO}_{2}}$ & Witega & + & $\mathrm{FBZ}_{-\mathrm{SO}_{2}-\mathrm{D} 5}$ \\
\hline Mebendazole & MBZ & Sigma-Aldrich & + & TBZ-D4 \\
\hline Hydroxy-Mebendazole & OH-MBZ & Janssen Animal Health (gift) & + & OH-MBZ-D3 \\
\hline Amino-Mebendazole & $\mathrm{NH}_{2}-\mathrm{MBZ}$ & Janssen Animal Health (gift) & + & TBZ-D4 \\
\hline Triclabendazole & TCB & Sigma-Aldrich & + & TCB-D3 \\
\hline Triclabendazole-Sulphoxide & TCB-SO & Witega & - & $\mathrm{TBCP}$ \\
\hline Triclabendazole-Sulphone & $\mathrm{TCB}-\mathrm{SO}_{2}$ & Witega & - & TBCP \\
\hline Keto-Triclabendazole & Keto-TCB & Witega & - & SALI \\
\hline Levamisole-D5 & LEVAM-D5 & QuChem (custom synthesis) & + & $*$ \\
\hline Albendazole-D3 & ABZ-D3 & Witega & + & $*$ \\
\hline Albendazole Sulphoxide-D3 & ABZ-SO-D3 & Witega & + & $*$ \\
\hline Albendazole Sulphone-D3 & $\mathrm{ABZ}-\mathrm{SO}_{2}-\mathrm{D} 3$ & Witega & + & $*$ \\
\hline Fenbendazole-D5 & FBZ-D5 & QuChem (custom synthesis) & + & $*$ \\
\hline Fenbendazole-Sulphoxide-D5 & FBZ-SO-D5 & QuChem (custom synthesis) & + & $*$ \\
\hline Fenbendazole-Sulphone-D5 & $\mathrm{FBZ}_{-\mathrm{SO}_{2}-\mathrm{D} 5}$ & QuChem (custom synthesis) & + & $*$ \\
\hline Thiabendazole-D4 & TBZ-D4 & QuChem (custom synthesis) & + & $*$ \\
\hline Triclabendazole-D3 & TCB-D3 & Witega & + & $*$ \\
\hline Hydroxy-Mebendazole-D3 & OH-MBZ-D3 & Witega & + & $*$ \\
\hline Selamectin & SELA & Pfizer Animal Health UK (gift) & + & $*$ \\
\hline Salicylanilide & SALI & Sigma-Aldrich & - & $*$ \\
\hline 2,2-Thiobis(4-chlorophenol) & ТВCP & Sigma-Aldrich & - & $*$ \\
\hline Dinitrocarbanilide-D8 & DNC-D8 & Witega & - & $*$ \\
\hline
\end{tabular}


Table 2. Parasiticidal preparations administered to beef cattle ( 450 kg body weight) and EU Maximum Residue Limits (MRL). NA $=$ none assigned.

\begin{tabular}{|c|c|c|c|c|c|c|c|c|}
\hline Brand name & Manufacturer & $\begin{array}{c}\text { Active ingredients } \\
\qquad(\% \mathrm{w} / \mathrm{v})\end{array}$ & $\begin{array}{c}\text { Dosage (mg kg-1 } \\
\text { body weight) }\end{array}$ & $\begin{array}{c}\text { Total dose } \\
\quad(\mathrm{mL})\end{array}$ & Route & $\begin{array}{l}\text { Days before } \\
\text { slaughter }\end{array}$ & $\begin{array}{l}\text { MRL bovine } \\
\text { muscle }\left(\mu \mathrm{g} \mathrm{kg}^{-1}\right)\end{array}$ & $\begin{array}{l}\text { MRL bovine } \\
\text { liver }\left(\mu \mathrm{g} \mathrm{kg}^{-1}\right.\end{array}$ \\
\hline $\begin{array}{c}\text { Fasinex Super® } \\
19.5 \%\end{array}$ & Novartis & $\begin{array}{l}\text { Triclabendazole } 12 \% \\
\text { Levamisole } \mathrm{HCl} 7.5 \%\end{array}$ & $\begin{array}{l}12 \\
7.5\end{array}$ & 45 & Oral & 2 & $\begin{array}{c}225 \\
10\end{array}$ & $\begin{array}{l}250 \\
100\end{array}$ \\
\hline $\begin{array}{l}\text { Supaverm } \\
\text { Oral Suspension }\end{array}$ & Janssen & $\begin{array}{c}\text { Mebendazole } 7.5 \% \\
\text { Closantel } 5 \%\end{array}$ & $\begin{array}{l}15 \\
10\end{array}$ & 90 & Oral & 1 & $\begin{array}{c}\text { NA } \\
1000\end{array}$ & $\begin{array}{l}\text { NA } \\
1000\end{array}$ \\
\hline Ivomec Super® & Merial & $\begin{array}{l}\text { Clorsulon } 10 \% \\
\text { Ivermectin } 1 \%\end{array}$ & $\begin{array}{c}2 \\
0.2\end{array}$ & 9 & $\begin{array}{l}\text { Injection } \\
\text { (subcut.) }\end{array}$ & 2 & $\begin{array}{c}35 \\
20 \text { (action limit) }\end{array}$ & $\begin{array}{l}100 \\
100\end{array}$ \\
\hline $\begin{array}{l}\text { Levafas } \\
\text { Diamond }\end{array}$ & Norbrook & $\begin{array}{l}\text { Oxyclozanide } 6 \% \\
\text { Levamisole } \mathrm{HCl} 3 \%\end{array}$ & $\begin{array}{l}15 \\
7.5\end{array}$ & 112.5 & Oral & 1 & $\begin{array}{l}20 \\
10\end{array}$ & $\begin{array}{l}500 \\
100\end{array}$ \\
\hline Deldrax® 34\% & Intervet & $\begin{array}{l}\text { Nitroxynil N- } \\
\text { ethylglucamine } 34 \%\end{array}$ & 10 & 13.5 & $\begin{array}{l}\text { Injection } \\
\text { (subcut.) }\end{array}$ & 2 & 400 & 20 \\
\hline Curafluke $10 \%$ & Univet & $\begin{array}{c}\text { Fenbendazole } 10 \% \\
\text { Rafoxanide } 10 \%\end{array}$ & $\begin{array}{l}11.25 \\
11.25\end{array}$ & 50.6 & Oral & 1 & $\begin{array}{l}50 \\
30\end{array}$ & $\begin{array}{c}500 \\
10\end{array}$ \\
\hline Valbazen® $10 \%$ & Pfizer & Albendazole $10 \%$ & 10 & 45 & Oral & 1 & 100 & 1000 \\
\hline
\end{tabular}


Table 3. Effect of frying on concentration of anthelmintic drug residues in bovine liver. Concentration data are mean \pm standard error ( $\mathrm{n}=3$ ). $\mathrm{P}$ value indicates a statistically significant difference between expected and observed concentrations after cooking. Expected concentrations are corrected for weight loss during cooking. $\mathrm{ND}=$ none detected (estimated assay Limit of Detection accounting for sample dilution).

\begin{tabular}{|c|c|c|c|c|c|c|c|}
\hline $\begin{array}{l}\text { LIVER } \\
\text { residue }\end{array}$ & $\begin{array}{c}\text { Weight } \\
\text { before }(g)\end{array}$ & $\begin{array}{l}\text { Weight } \\
\text { after }(g)\end{array}$ & $\begin{array}{l}\text { Max. internal } \\
\text { temp. }\left({ }^{\circ} \mathbf{C}\right)\end{array}$ & $\begin{array}{l}\mu \mathrm{g} \mathrm{kg}^{-1} \\
\text { uncooked }\end{array}$ & $\begin{array}{l}\mu \mathrm{g} \mathrm{kg}^{-1} \text { expected } \\
\text { after frying }\end{array}$ & $\begin{array}{l}\mu \mathrm{g} \mathrm{kg}^{-1} \text { observed after } \\
\text { frying }\end{array}$ & $\begin{array}{l}\text { Residues \% change } \\
\text { during frying }\end{array}$ \\
\hline Levamisole & 143.0 & 103.7 & 91.3 & $2928.6 \pm 65.0$ & $4038.5 \pm 89.6$ & $2332.6 \pm 43.2 \quad(\mathrm{P}<0.0001)$ & -42 \\
\hline Oxyclozanide & 143.0 & 103.7 & 91.3 & $4014.7 \pm 243.1$ & $5536.2 \pm 335.2$ & $5861.0 \pm 90.4$ & +6 \\
\hline Closantel & 133.4 & 99.2 & 92.4 & $5652.8 \pm 881.3$ & $7601.7 \pm 1185.1$ & $7654.9 \pm 692.2$ & +1 \\
\hline Nitroxynil & 209.5 & 133.8 & 96.1 & $\mathrm{ND}(<10)$ & $\mathrm{ND}(<10)$ & $\mathrm{ND}(<10)$ & $*$ \\
\hline Clorsulon & 187.5 & 144.9 & 88.7 & $1470.2 \pm 19.3$ & $1902.5 \pm 24.9$ & $1727.3 \pm 105.5$ & -9 \\
\hline Ivermectin & 187.5 & 144.9 & 88.7 & $487.2 \pm 35.2$ & $630.4 \pm 45.6$ & $485.9 \pm 61.6$ & -23 \\
\hline Rafoxanide & 165.5 & 113.6 & 88.0 & $3160.2 \pm 334.8$ & $4604.0 \pm 487.7$ & $4056.3 \pm 171.1$ & -12 \\
\hline $\mathrm{ABZ}$ & 154.2 & 108.0 & 93.7 & $1112.2 \pm 20.0$ & $1588.0 \pm 28.6$ & $1368.6 \pm 39.8 \quad(\mathrm{P}<0.02)$ & -14 \\
\hline ABZ-SO & 154.2 & 108.0 & 93.7 & $290.2 \pm 6.3$ & $414.3 \pm 8.9$ & $256.6 \pm 25.4(\mathrm{P}<0.005)$ & -38 \\
\hline $\mathrm{ABZ}-\mathrm{SO}_{2}$ & 154.2 & 108.0 & 93.7 & $1403.9 \pm 108.8$ & $2004.5 \pm 155.4$ & $1854.8 \pm 89.4$ & -8 \\
\hline $\mathrm{ABZ}-\mathrm{NH}_{2}-\mathrm{SO}_{2}$ & 154.2 & 108.0 & 93.7 & $720.3 \pm 21.4$ & $1028.4 \pm 30.6$ & $1211.9 \pm 43.2 \quad(\mathrm{P}<0.03)$ & +18 \\
\hline SUM ABZ & 154.2 & 108.0 & 93.7 & $2324.8 \pm 78.4$ & $3319.3 \pm 111.9$ & $3240.4 \pm 99.7$ & -2 \\
\hline MBZ & 133.4 & 99.2 & 92.4 & $22.4 \pm 1.0$ & $30.2 \pm 1.4$ & $33.2 \pm 2.0$ & +10 \\
\hline OH-MBZ & 133.4 & 99.2 & 92.4 & $73.2 \pm 2.1$ & $98.4 \pm 2.8$ & $99.7 \pm 7.3$ & +1 \\
\hline $\mathrm{NH}_{2}-\mathrm{MBZ}$ & 133.4 & 99.2 & 92.4 & $297.8 \pm 25.4$ & $400.4 \pm 34.2$ & $833.5 \pm 142.8 \quad(\mathrm{P}<0.05)$ & +108 \\
\hline SUM MBZ & 133.4 & 99.2 & 92.4 & $467.0 \pm 32.4$ & $628.0 \pm 43.6$ & $1171.2 \pm 174.3(P<0.04)$ & +86 \\
\hline FBZ & 165.5 & 113.6 & 88.0 & $9243 \pm 998$ & $13466 \pm 1454$ & $13623 \pm 251$ & +1 \\
\hline FBZ-SO & 165.5 & 113.6 & 88.0 & $1791.1 \pm 90.8$ & $2609.3 \pm 132.3$ & $525.6 \pm 21.0 \quad(\mathrm{P}<0.0001)$ & -80 \\
\hline $\mathrm{FBZ}-\mathrm{SO}_{2}$ & 165.5 & 113.6 & 88.0 & $1029.4 \pm 76.0$ & $1499.7 \pm 110.7$ & $1637.3 \pm 111.9$ & +9 \\
\hline SUM FBZ & 165.5 & 113.6 & 88.0 & $13144 \pm 1085$ & $19149 \pm 1581$ & $17270 \pm 387$ & -10 \\
\hline TCB & 186.3 & 138.0 & 89.7 & $2911.0 \pm 43.9$ & $3929.9 \pm 59.3$ & $3160.4 \pm 183.2(\mathrm{P}<0.02)$ & -20 \\
\hline TCB-SO & 186.3 & 138.0 & 89.7 & $\mathrm{ND}(<50)$ & $\mathrm{ND}(<50)$ & $\mathrm{ND}(<50)$ & $*$ \\
\hline TCB-SO ${ }_{2}$ & 186.3 & 138.0 & 89.7 & $1162.9 \pm 85.5$ & $1569.9 \pm 115.4$ & $988.6 \pm 53.1 \quad(\mathrm{P}<0.02)$ & -37 \\
\hline Keto-TCB & 186.3 & 138.0 & 89.7 & $383.8 \pm 34.2$ & $518.2 \pm 46.2$ & $453.7 \pm 133.0$ & -12 \\
\hline SUM TCB & 186.3 & 138.0 & 89.7 & $4029.5 \pm 171.7$ & $5439.8 \pm 231.8$ & $4181.0 \pm 246.9(P<0.03)$ & -23 \\
\hline
\end{tabular}


Table 4. Effect of frying on concentration of anthelmintic drug residues in bovine muscle. Tissue concentration data are mean \pm standard error $(\mathrm{n}=3)$. Juice concentration data are means $(\mathrm{n}=2)$. NA $=$ not available. $\mathrm{ND}=$ none detected (estimated assay Limit of Detection accounting for sample dilution). $\mathrm{P}$ value indicates a statistically significant difference between expected and observed concentrations after cooking.

\begin{tabular}{|c|c|c|c|c|c|c|c|c|c|c|}
\hline $\begin{array}{l}\text { MUSCLE } \\
\text { residue }\end{array}$ & $\begin{array}{l}\text { Weight } \\
\text { before }(g)\end{array}$ & $\begin{array}{l}\text { Weight } \\
\text { after (g) }\end{array}$ & $\begin{array}{l}\text { Weight } \\
\text { juices }(\mathrm{g})\end{array}$ & $\begin{array}{l}\text { Max. internal } \\
\text { temp. }\left({ }^{\circ} \mathbf{C}\right)\end{array}$ & $\begin{array}{l}\mu \mathrm{g} \mathrm{kg}^{-1} \\
\text { uncooked }\end{array}$ & $\begin{array}{l}\mu \mathrm{g} \mathrm{kg} \mathbf{~}^{-1} \text { expected } \\
\text { after frying }\end{array}$ & $\begin{array}{l}\mu \mathrm{g} \mathrm{kg}^{-1} \text { observed after } \\
\text { frying }\end{array}$ & $\begin{array}{l}\mu \mathbf{g ~ k g}^{-1} \\
\text { juices }\end{array}$ & $\begin{array}{l}\% \text { of total fried } \\
\text { residue in juices }\end{array}$ & $\begin{array}{l}\text { Residue \% change } \\
\text { during frying (juices } \\
\text { included) }\end{array}$ \\
\hline Levamisole & 189.6 & 151.2 & 0 & 57.0 & $108.1 \pm 0.9$ & $135.5 \pm 1.2$ & $121.3 \pm 0.3(\mathrm{P}<0.0003)$ & NA & NA & -11 \\
\hline Oxyclozanide & 189.6 & 151.2 & 0 & 57.0 & $547.5 \pm 14.9$ & $686.5 \pm 18.7$ & $868.6 \pm 22.1(\mathrm{P}<0.004)$ & NA & NA & +27 \\
\hline Closantel & 149.2 & 117.5 & 3.4 & 67.3 & $2089.8 \pm 74.7$ & $2653.6 \pm 94.8$ & $2499.9 \pm 95.0$ & 684.8 & $<1$ & -5 \\
\hline Nitroxynil & 248.1 & 196.0 & 4.0 & 66.9 & $531.4 \pm 7.2$ & $672.7 \pm 9.2$ & $142.9 \pm 9.7(\mathrm{P}<0.0001)$ & 238.5 & 3 & -78 \\
\hline Clorsulon & 151.1 & 119.5 & 3.9 & 70.2 & $289.2 \pm 10.3$ & $365.7 \pm 13.0$ & $470.0 \pm 28.3(\mathrm{P}<0.03)$ & $\mathrm{ND}(<150)$ & 0 & +29 \\
\hline Ivermectin & 151.1 & 119.5 & 3.9 & 70.2 & $14.4 \pm 0.6$ & $18.1 \pm 0.7$ & $15.6 \pm 0.9$ & NA & NA & -14 \\
\hline Rafoxanide & 124.2 & 88.0 & 3.6 & 68.6 & $1813.3 \pm 49.1$ & $2559.2 \pm 69.4$ & $2106.8 \pm 125.0(\mathrm{P}<0.04)$ & 133.3 & $<1$ & -17 \\
\hline ABZ & 227.6 & 170.5 & 0 & 55.0 & $5.30 \pm 0.09$ & $7.07 \pm 0.12$ & $7.02 \pm 0.12$ & NA & NA & -1 \\
\hline ABZ-SO & 227.6 & 170.5 & 0 & 55.0 & $1.58 \pm 0.36$ & $2.11 \pm 0.48$ & $\mathrm{ND}(<1)(\mathrm{P}<0.02)$ & NA & NA & -100 \\
\hline $\mathrm{ABZ}-\mathrm{SO}_{2}$ & 227.6 & 170.5 & 0 & 55.0 & $42.4 \pm 0.4$ & $56.6 \pm 0.6$ & $47.2 \pm 0.3(\mathrm{P}<0.0002)$ & NA & NA & -17 \\
\hline $\mathrm{ABZ}-\mathrm{NH}_{2}-\mathrm{SO}_{2}$ & 227.6 & 170.5 & 0 & 55.0 & $106.0 \pm 4.5$ & $141.5 \pm 6.0$ & $164.9 \pm 2.1(\mathrm{P}<0.03)$ & $\mathrm{NA}$ & $\mathrm{NA}$ & +17 \\
\hline SUM ABZ & 227.6 & 170.5 & $\mathbf{0}$ & 55.0 & $156.9 \pm 5.2$ & $209.4 \pm 6.9$ & $225.0 \pm 2.6$ & NA & NA & +7 \\
\hline MBZ & 149.2 & 117.5 & 0 & 67.3 & $0.89 \pm 0.05$ & $1.13 \pm 0.06$ & $1.01 \pm 0.06$ & NA & NA & -10 \\
\hline OH-MBZ & 149.2 & 117.5 & 0 & 67.3 & $8.75 \pm 0.11$ & $11.1 \pm 0.1$ & $8.34 \pm 0.31(\mathrm{P}<0.002)$ & NA & NA & -25 \\
\hline $\mathrm{NH}_{2}-\mathrm{MBZ}$ & 149.2 & 117.5 & 0 & 67.3 & $23.1 \pm 0.7$ & $29.3 \pm 0.9$ & $30.0 \pm 0.3$ & NA & NA & +2 \\
\hline SUM MBZ & 149.2 & 117.5 & $\mathbf{0}$ & 67.3 & $38.5 \pm 0.9$ & $48.9 \pm 1.1$ & $46.8 \pm 0.1$ & NA & NA & -4 \\
\hline FBZ & 124.2 & 88.0 & 3.6 & 68.6 & $265.3 \pm 7.8$ & $374.5 \pm 11.0$ & $340.0 \pm 4.0(\mathrm{P}<0.05)$ & 7.75 & $<1$ & -9 \\
\hline FBZ-SO & 124.2 & 88.0 & 3.6 & 68.6 & $5.57 \pm 0.19$ & $7.86 \pm 0.26$ & $2.53 \pm 0.09(\mathrm{P}<0.0001)$ & $\mathrm{ND}(<2)$ & 0 & -68 \\
\hline FBZ-SO ${ }_{2}$ & 124.2 & 88.0 & 3.6 & 68.6 & $154.6 \pm 1.6$ & $218.2 \pm 2.3$ & $209.5 \pm 13.6$ & 24.9 & $<1$ & -4 \\
\hline SUM FBZ & 124.2 & 88.0 & 3.6 & 68.6 & $454.2 \pm 9.6$ & $641.1 \pm 13.6$ & $588.5 \pm 17.5$ & 33.4 & $<1$ & -8 \\
\hline $\mathrm{TCB}$ & 205.5 & 158.5 & 3.9 & 72.0 & $292.4 \pm 9.7$ & $379.1 \pm 12.6$ & $617.0 \pm 27.9(\mathrm{P}<0.002)$ & 16.2 & $<1$ & +63 \\
\hline TCB-SO & 205.5 & 158.5 & 3.9 & 72.0 & $72.1 \pm 4.0$ & $93.5 \pm 5.2$ & $23.1 \pm 1.6(\mathrm{P}<0.0003)$ & $\mathrm{ND}(<50)$ & 0 & -75 \\
\hline TCB-SO & 205.5 & 158.5 & 3.9 & 72.0 & $2674.4 \pm 165.3$ & $3467.4 \pm 214.3$ & $2953.6 \pm 175.9$ & 55.6 & $<1$ & -15 \\
\hline Keto-TCB & 205.5 & 158.5 & 3.9 & 72.0 & $52.6 \pm 0.4$ & $68.2 \pm 0.5$ & $96.7 \pm 3.3(\mathrm{P}<0.001)$ & $\mathrm{ND}(<50)$ & 0 & +42 \\
\hline SUM TCB & 205.5 & 158.5 & 3.9 & 72.0 & $2635.5 \pm 149.2$ & $3417 \pm 193.5$ & $3169.1 \pm 169.2$ & 61.6 & $<1$ & -7 \\
\hline
\end{tabular}

http://mc.manuscriptcentral.com/tfac Email: fac@tandf.co.uk 
Table 5. Effect of roasting on concentration of anthelmintic drug residues in bovine muscle. Tissue concentration data are mean \pm standard error $(\mathrm{n}=3)$. Juice concentration data are means $(\mathrm{n}=2) . \mathrm{NA}=$ not available. $\mathrm{ND}=$ none detected (estimated assay Limit of Detection accounting for sample dilution). $\mathrm{P}$ value indicates a statistically significant difference between expected and observed concentrations after cooking.

\begin{tabular}{|c|c|c|c|c|c|c|c|c|c|c|}
\hline $\begin{array}{l}\text { MUSCLE } \\
\text { residue }\end{array}$ & $\begin{array}{c}\text { Weight } \\
\text { before (g) }\end{array}$ & $\begin{array}{c}\text { Weight } \\
\text { after }(g)\end{array}$ & $\begin{array}{c}\text { Weight } \\
\text { juices (g) }\end{array}$ & $\begin{array}{c}\text { Max. } \\
\text { internal } \\
\text { temp. }\left({ }^{\circ} \mathrm{C}\right)\end{array}$ & $\begin{array}{l}\mu \mathrm{g} \mathrm{kg}^{-1} \\
\text { uncooked }\end{array}$ & $\begin{array}{l}\mu \mathrm{kg}^{-1} \text { expected } \\
\text { after roasting }\end{array}$ & $\begin{array}{l}\mu \mathrm{g} \mathrm{kg}^{-1} \text { observed after } \\
\text { roasting }\end{array}$ & $\begin{array}{l}\mu \mathrm{kg}^{-1} \\
\text { juices }\end{array}$ & $\begin{array}{l}\% \text { of total } \\
\text { roasted residue } \\
\text { in juices }\end{array}$ & $\begin{array}{l}\text { Residue \% change } \\
\text { during roasting } \\
\text { (juices included) }\end{array}$ \\
\hline Levamisole & 278.1 & 190.4 & 31.2 & 87.0 & $108.1 \pm 0.9$ & $157.8 \pm 1.3$ & $131.7 \pm 1.5(\mathrm{P}<0.0003)$ & 164.1 & 17 & +1 \\
\hline Oxyclozanide & 278.1 & 190.4 & 31.2 & 87.0 & $547.5 \pm 14.9$ & $799.6 \pm 21.8$ & $728.2 \pm 31.6$ & $\mathrm{ND}(<25)$ & 0 & -9 \\
\hline Closantel & 314.2 & 206.5 & 49.7 & 92.9 & $2089.8 \pm 74.7$ & $3179.7 \pm 113.6$ & $3447.7 \pm 117.5$ & 20.0 & $<1$ & +9 \\
\hline Nitroxynil & 311.6 & 198.9 & 68.3 & 92.8 & $531.4 \pm 7.2$ & $832.6 \pm 11.4$ & $34.3 \pm 0.9(\mathrm{P}<0.0001)$ & $\mathrm{ND}(<10)$ & 0 & -96 \\
\hline Clorsulon & 314.7 & 211.4 & 54.1 & 84.2 & $289.2 \pm 10.3$ & $430.6 \pm 15.3$ & $463.2 \pm 41.8$ & 117.5 & 6 & +15 \\
\hline Ivermectin & 314.7 & 211.4 & 54.1 & 84.2 & $14.4 \pm 0.6$ & $21.4 \pm 0.9$ & $26.9 \pm 2.9$ & ND $(<5)$ & 0 & +26 \\
\hline Rafoxanide & 262.9 & 169.3 & 45.0 & 87.6 & $1813.3 \pm 49.1$ & $2815.8 \pm 76.3$ & $2313.6 \pm 114.9(\mathrm{P}<0.03)$ & 17.8 & $<1$ & -18 \\
\hline $\mathrm{ABZ}$ & 325.1 & 224.5 & 35.0 & 82.0 & $5.30 \pm 0.09$ & $7.67 \pm 0.13$ & $6.28 \pm 0.05(\mathrm{P}<0.0006)$ & 0.47 & 1 & -17 \\
\hline ABZ-SO & 325.1 & 224.5 & 35.0 & 82.0 & $1.58 \pm 0.36$ & $2.29 \pm 0.52$ & $2.91 \pm 0.35$ & 1.37 & 7 & +36 \\
\hline $\mathrm{ABZ}-\mathrm{SO}_{2}$ & 325.1 & 224.5 & 35.0 & 82.0 & $42.4 \pm 0.4$ & $61.4 \pm 0.6$ & $54.8 \pm 1.5(\mathrm{P}<0.02)$ & 28.6 & 8 & -3 \\
\hline $\mathrm{ABZ}-\mathrm{NH}_{2}-\mathrm{SO}_{2}$ & 325.1 & 224.5 & 35.0 & 82.0 & $106.0 \pm 4.5$ & $153.5 \pm 6.5$ & $129.4 \pm 1.9(\mathrm{P}<0.03)$ & 77.4 & 9 & -8 \\
\hline SUM ABZ & 325.1 & 224.5 & 35.0 & 82.0 & $156.9 \pm 5.2$ & $227.1 \pm 7.5$ & $195.1 \pm 3.6(P<0.02)$ & 112.7 & 8 & -6 \\
\hline MBZ & 314.2 & 206.5 & 49.7 & 92.9 & $0.89 \pm 0.05$ & $1.36 \pm 0.07$ & $0.93 \pm 0.02(\mathrm{P}<0.004)$ & 0.23 & 6 & -28 \\
\hline OH-MBZ & 314.2 & 206.5 & 49.7 & 92.9 & $8.75 \pm 0.11$ & $13.3 \pm 0.2$ & $13.4 \pm 0.5$ & 3.36 & 6 & +6 \\
\hline $\mathrm{NH}_{2}$-MBZ & 314.2 & 206.5 & 49.7 & 92.9 & $23.1 \pm 0.7$ & $35.1 \pm 1.1$ & $29.1 \pm 0.8(\mathrm{P}<0.01)$ & 11.8 & 9 & -9 \\
\hline SUM MBZ & 314.2 & 206.5 & 49.7 & 92.9 & $38.5 \pm 0.9$ & $58.6 \pm 1.3$ & $50.6 \pm 1.2(\mathrm{P}<0.02)$ & 18.3 & 8 & -6 \\
\hline FBZ & 262.9 & 169.3 & 45.0 & 87.6 & $265.3 \pm 7.8$ & $412.0 \pm 12.1$ & $386.9 \pm 7.0$ & 12.3 & 1 & -5 \\
\hline FBZ-SO & 262.9 & 169.3 & 45.0 & 87.6 & $5.57 \pm 0.19$ & $8.64 \pm 0.29$ & $21.5 \pm 1.4(\mathrm{P}<0.0009)$ & 13.7 & 14 & +190 \\
\hline${\mathrm{FBZ}-\mathrm{SO}_{2}}_{2}$ & 262.9 & 169.3 & 45.0 & 87.6 & $154.6 \pm 1.6$ & $240.1 \pm 2.5$ & $250.3 \pm 3.7$ & 39.4 & 4 & +9 \\
\hline SUM FBZ & 262.9 & 169.3 & 45.0 & 87.6 & $454.2 \pm 9.6$ & $705.3 \pm 14.9$ & $701.2 \pm 5.9$ & 67.3 & 2 & +2 \\
\hline TCB & 302.2 & 203.1 & 44.9 & 88.3 & $292.4 \pm 9.7$ & $435.0 \pm 14.5$ & $475.3 \pm 46.8$ & 2.87 & $<1$ & +9 \\
\hline TCB-SO & 302.2 & 203.1 & 44.9 & 88.3 & $72.1 \pm 4.0$ & $107.3 \pm 6.0$ & $8.50 \pm 0.88(\mathrm{P}<0.0001)$ & ND $(<2)$ & 0 & -92 \\
\hline TCB-SO ${ }_{2}$ & 302.2 & 203.1 & 44.9 & 88.3 & $2674.4 \pm 165.3$ & $3979.3 \pm 246.0$ & $1869.8 \pm 65.5(\mathrm{P}<0.002)$ & 18.5 & $<1$ & -53 \\
\hline Keto-TCB & 302.2 & 203.1 & 44.9 & 88.3 & $52.6 \pm 0.4$ & $78.2 \pm 0.6$ & $68.2 \pm 3.5(\mathrm{P}<0.05)$ & $\mathrm{ND}(<20)$ & 0 & -13 \\
\hline SUM TCB & 302.2 & 203.1 & 44.9 & 88.3 & $2635.5 \pm 149.2$ & $3921.5 \pm 222.0$ & $2085.4 \pm 94.3(P<0.002)$ & 18.2 & $<1$ & -47 \\
\hline
\end{tabular}

http://mc.manuscriptcentral.com/tfac Email: fac@tandf.co.uk 